\title{
EFEKTIFITAS BERBAGAI KOMPOSISI MEDIA TANAM DAN DOSIS PUPUK GANDASIL D TERHADAP PERTUMBUHAN TANAMAN PUCUK MERAH (Syzygium campanulatum K.) PADA PERSEMAIAN
}

\author{
Revi Razip Bernatha'), Wahid Erawan'), dan Atak Tauhid ${ }^{2)}$ \\ 1) Mahasiswa Fakultas Pertanian Universitas Garut \\ 2) Dosen Fakultas Pertanian Universitas Garut \\ E-mail : ataktauhid12@gmail.com
}

\begin{abstract}
ABSTRAK
Penelitian dilaksanakan untuk mempelajari pengaruh berbagai komposisi media tanam dan dosis pupuk Gandasil D terhadap pertumbuhan tanaman pucuk merah. Penelitian dilaksanakan di Kp. Babakan Jambe Desa Pasawahan Kecamatan Tarogong Kaler Kabupaten Garut Provinsi Jawa Barat, dengan ketinggian tempat $738 \mathrm{~m}$ di atas permukaan laut. Jenis tanah adalah Inceptisol dengan kemasaman tanah 6,8. Penelitian ini dilakukan pada bulan Maret sampai Juli 2017. Metode yang digunakan dalam penelitian ini adalah eksperimental menggunakan Rancangan Acak Kelompok (RAK) pola faktorial 4 x 4 diulang 2 kali. Faktor pertama komposisi media tanam (M) terdiri atas empat taraf, yaitu : $\mathrm{m}_{1}=\operatorname{tanah}$ : bokashi : sekam $(50: 25: 25), \mathrm{m}_{2}=$ tanah $:$ bokashi $:$ arang sekam $(25: 50: 25), \mathrm{m}_{3}=$ tanah : bokashi : serbuk gergaji $(25: 25: 50)$, dan $\mathrm{m}_{4}=$ tanah : bokashi : cocopeat $(50$ : 25 :25). Faktor kedua dosis pupuk Gandasil D (G) yang terdiri atas empat taraf, yaitu: $\mathrm{g}_{1}=0$ gram (kontrol), $\mathrm{g}_{2}=1 \mathrm{gram} /$ polybag, $\mathrm{g}_{3}=2 \mathrm{gram} /$ polybag, $\mathrm{g}_{4}=3$ gram/polybag. Hasil penelitian menunjukkan tidak terjadi interaksi antara berbagai komposisi media tanam dan dosis Gandasil D terhadap pertumbuhan tanaman pucuk merah. Pengaruh berbagai komposisi media tanah : bokashi : cocopeat ( 50 : $25: 25$ ) berpengaruh nyata terhadap tinggi tanaman, jumlah daun, luas daun, bobot kering tanaman, diameter batang, dan panjang akar. Pengaruh dosis pupuk gandasil D, 2 gram/polybag berpengaruh nyata terhadap tinggi tanaman, jumlah daun, luas daun, bobot kering tanaman, diameter batang dan panjang akar.
\end{abstract}

Kata kunci : Media tanam, pupuk Gandasil D, tanaman pucuk merah. 


\begin{abstract}
The study was conducted to study the effect of various planting media compositions and dosage of Gandasil D fertilizer on the growth of red shoots. The research was conducted in Kp. Babakan Jambe Pasawahan Village Tarogong Kaler District Garut Regency West Java Province, with a height of $738 \mathrm{~m}$ above sea level. Soil type is Inceptisol with soil acidity of 6.8. This research was conducted from March to July 2017. The method used in this research is experimental using Randomized Block Design (RAK) $4 \times 4$ factorial pattern repeated 2 times. The first factor of planting media composition $(M)$ consists offour levels, namely: $m 1$ = soil: bokashi: husk (50: 25: 25), $m 2$ = soil: bokashi: $\operatorname{chaff}$ charcoal (25: 50: 25), m3 = bokashi: sawdust (25: 25: 50), and $m 4$ = soil: bokashi: cocopeat (50: 25: 25). The second factor of dose of Gandasil D $(G)$ fertilizer consisting of four levels, namely: $g 1=0$ gram (control), g2 = 1 gram $/$ polybag, g3 = 2 gram $/$ polybag, g4 = $3 \mathrm{gram} /$ polybag. The results showed no interaction between various planting media composition and dose of Gandasil D on the growth of red shoot plants. The influence of various soil media compositions: bokashi: cocopeat (50:25: 25) had significant effect on plant height, leaf number, leaf area, plant dry weight, stem diameter, and root length. The effect of dosage of DG, 2 gram / polybag has significant effect on plant height, leaf number, leaf area, dry weight of plant, stem diameter and root length.
\end{abstract}

Keywords: Planting media, Gandasil D fertilizer, red shoots plant.

\title{
PENDAHULUAN
}

Tanaman hias memiliki nilai estetika karena bentuk, warna, tekstur maupun aromanya. Tanaman hias terbagi menjadi tanaman hias bunga, tanaman hias daun, tanaman hias tajuk dan tanaman hias akar, dari ke-empat jenis tanaman hias tersebut, tanaman hias daun cenderung lebih cocok ditanam di luar. Hal ini karena tanaman hias daun relatif lebih tahan lama dan lebih mudah beradaptasi. Tanaman hias daun berbeda dengan tanaman hias bunga, tanaman hias daun mempunyai daya tarik tersendiri pada bagian daunnya. Daya tarik jenis tanaman ini dapat disebabkan oleh bentuk, keadaan, warna, walaupun komposisi daun dengan batang yang indah. Tanaman hias daun salahsatunya yang memiliki keindahan daun dengan bentuk dan warna yang menarik adalah Pucuk Merah.

Pucuk merah memiliki warna daun merah, kuning, hijau muda dan hijau tua, tidak hanya daunnya yang beraneka warna, tetapi juga jumlah daun serta cabangnya yang banyak memberikan kesan rimbun. Tanaman Pucuk merah selain memberikan nilai estetika, juga memiliki serapan yang baik terhadap kandungan 
CO2 di udara. Maka sangat cocok untuk suatu upaya penghijauan di lingkungan rumah ataupun tata kota (Aisha, $d k k, 2013$ ).

Potensi serta prospek tanaman hias termasuk pucuk merah menjadi primadona bagi kalangan masyarakat. Setiap tahunnya terus terjadi peningkatan, data terakhir pada tahun 2011 tercatat data volume senilai US\$ 13.160.381. Berdasarkan penjelasan tersebut prospek pengembangan tanaman hias sangat baik dipasaran (Direktorat Jendral Hortikultura, 2012). Upaya yang dapat memperbaiki kendala seperti tidak tersedianya unsur hara pada tanaman. Baik unsur hara makro maupun mikro pada berbagai jenis tanah yang kurang subur adalah dengan penggunaan media tanam dan pemberian pupuk atau unsur hara (Pinus Lingga, 2001) Faktor yang mempengaruhi pertumbuhan tanaman selain faktor internal atau genetik juga faktor eksternal atau lingkungan tumbuh. Lingkungan tumbuh dapat berupa media tumbuh tanaman. Media tumbuh yang baik adalah media yang mampu menyediakan air dan unsur hara dalam jumlah cukup bagi pertumbuhan bibit. Hal ini dapat ditemukan pada tanah dengan tata udara dan air yang baik, perakaran yang cukup.

Media tanam adalah media atau bahan yang digunakan sebagai tempat tumbuh dan berkembangnya akar tanaman. Media tanam dapat berupa tanah maupun non tanah. Fungsi penting media tanam adalah penopang tanaman terutama bagi tanaman yang dipelihara di dalam pot atau polybag agar tumbuh baik, penyedia unsur hara dan penyedia air bagi tanaman. Jenis media tanam banyak dipasaran akan tetapi media tersebut harus memiliki sifat yang dibutuhkan oleh tanaman. Mengandung unsur hara dan mempunyai daya simpan yang optimal adalah salah satunya.

Pertumbuhan vegetatif yang baik dapat tercapai bila faktor - faktor yang menunjang pertumbuhan tanaman dalam keadaan optimum. Unsur hara yang lengkap yaitu yang mengandung unsur makro N, P dan K, serta kandungan mikro seperti Mn, B, Cu, Co, Mo dan Zn, kemudian vitamin seperti aneurine, lactofla dan amid. Kandungan hara itu diperlukan tanaman untuk berbagai kegunaan dalam pertumbuhan tanaman yang dapat mempercepat pertumbuhan, tinggi, jumlah daun, luas daun dan percabangan. Berdasarkan hal tersebut, maka diperlukan suatu kajian mengenai pengujian "Pengaruh Berbagai Komposisi Media Tanam dan Dosis Pupuk Gandasil D Terhadap Pertumbuhan Tanaman Pucuk Merah (Syzygium Campanulatum K.) Pada Persemaian”.

\section{METODE PENELITIAN}

Percobaan dilaksanakan di Kampung Babakan Jambe Desa Pasawahan Kecamatan Tarogong Kaler Kabupaten Garut. Ketinggian tempat 738 m di atas permukaan laut, jenis tanah Inceptisol dengan keasaman tanah 6,8 (netral). 
Percobaan dilaksanakan pada bulan Maret sampai dengan bulan Juli 2017. Berdasarkan kriteria Schmidt and Ferguson (1951) adalah tipe curah hujan C.

Metode yang digunakan dalam penelitian adalah eksperimental dengan menggunakan Rancangan Acak Kelompok (RAK) pola Faktorial 4 x 4 dengan 2 ulangan. Faktor pertama adalah komposisi media tanam (m) yang terdiri atas empat taraf, yaitu:

$\mathrm{m}_{1}=$ Tanah : Bokashi : Sekam $(50: 25: 25)$

$\mathrm{m}_{2}=$ Tanah $:$ Bokashi : Arang sekam $(25: 50: 25)$

$\mathrm{m}_{3}=$ Tanah $:$ Bokashi $:$ Serbuk gergaji $(25: 25: 50)$

$\mathrm{m}_{4}=$ Tanah : Bokashi : Cocopeat $(50: 25: 25)$

Faktor kedua adalah dosis pupuk daun Gandasil D (g) terdiri atas empat taraf, yaitu :

$\mathrm{g}_{1}=0$ gram / polybag

$\mathrm{g}_{2}=1$ gram / polybag

$\mathrm{g}_{3}=2$ gram / polybag

$\mathrm{g}_{4}=3$ gram / polybag

Terdapat 16 kombinasi taraf perlakuan yang diulang dua kali sehingga jumlah plot perlakuan adalah 32 plot dan satu plot terdiri dari 10 polybag jadi seluruhnya 320 polybag.

Pengamatan dilakukan dengan mengamati komponen pertumbuhan vegetative untuk mengetahui pengaruh setiap perlakuan diantaranya tinggi tanaman, jumlah daun, luas daun, bobot kering, diameter batang dan panjang akar

\section{HASIL DAN PEMBAHASAN}

\section{Tinggi Tanaman $(\mathbf{c m})$}

Hasil analisis statistik menunjukkan tidak terjadi interaksi antara berbagai komposisi media tanam (M) dengan berbagai dosis pupuk Gandasil D (G) terhadap tinggi tanaman pucuk merah. Namun secara mandiri memberikan pengaruh nyata (Tabel 1). 


\section{Tabel 1. Respon Tanaman Pucuk Merah Terhadap Berbagai Komposisi Media Tanam dan Dosis Pupuk Gandasil D Terhadap Tinggi Tanaman 30, 60 dan 90 HST.}

\begin{tabular}{lccc}
\hline \multicolumn{1}{c}{ Perlakuan } & \multicolumn{3}{c}{ Rata - rata } \\
& 30 HST & 60 HST & 90 HST \\
\hline Komposisi Media Tanam $(\mathrm{M})$ & & & \\
$\mathrm{m}_{1}=$ Tanah : Bokashi : Sekam $(50: 25: 25)$ & $11,56 \mathrm{a}$ & $16,89 \mathrm{a}$ & $25,74 \mathrm{a}$ \\
$\mathrm{m}_{2}=$ Tanah : Bokashi : Arang sekam(25:50:25) & $11,77 \mathrm{a}$ & $17,53 \mathrm{~b}$ & $26,14 \mathrm{~b}$ \\
$\mathrm{~m}_{3}=$ Tanah : Bokashi : Serbuk gergaji(25:25:50) & $11,20 \mathrm{a}$ & $15,72 \mathrm{a}$ & $24,54 \mathrm{a}$ \\
$\mathrm{m}_{4}=$ Tanah : Bokashi : Cocopeat $(50: 25: 25)$ & $11,98 \mathrm{~b}$ & $17,59 \mathrm{~b}$ & $26,90 \mathrm{~b}$ \\
\hline Dosis Pupuk Gandasil D $(\mathrm{G})$ & & & \\
$\mathrm{g}_{1}=$ 0 gram/polybag & $11,64 \mathrm{a}$ & $16,10 \mathrm{a}$ & $24,08 \mathrm{a}$ \\
$\mathrm{g}_{2}=1$ gram/polybag & $11,56 \mathrm{a}$ & $17,23 \mathrm{a}$ & $26,01 \mathrm{~b}$ \\
$\mathrm{~g}_{3}=2$ gram/polybag & $11,92 \mathrm{a}$ & $17,56 \mathrm{~b}$ & $27,92 \mathrm{c}$ \\
$\mathrm{g}_{4}=3$ gram/polybag & $11,39 \mathrm{a}$ & $16,84 \mathrm{a}$ & $25,30 \mathrm{a}$ \\
\hline
\end{tabular}

Keterangan: Angka rata-rata yang diikuti huruf yang sama pada setiap kolom berbeda tidak nyata menurut Uji Jarak Berganda Duncan taraf 5\%.

Taraf faktor $\mathrm{m}_{4}$, yaitu campuran media tanah, bokashi dan cocopeat komposisi $(50: 25: 25)$, menunjukan rata - rata tinggi tanaman yang lebih tinggi dari taraf faktor lainnya pada setiap periode pengamatan 30, 60 dan 90 HST. Hal ini diduga penambahan cocopeat pada media tanah dan bokashi dapat menambah bahan organik tanah dan humus. Memperbaiki sifat fisik tanah, daya mengikat air dan porositas tanah, meningkatkan kesuburan tanah dengan memperbaiki kehidupan mikroorganisme tanah (Styamidjaya, 1986).

Faktor perlakuan $\mathrm{g}_{3}$ yaitu dosis pupuk Gandasil 2 gram/polybag menunjukan rata - rata tinggi tanaman yang lebih tinggi dari faktor lainnya pada setiap periode pengamatan 30, 60 dan 90 HST. Hal ini diduga pupuk Gandasil D sebagai pengimbang dari pemupukan melalui tanah dan unsur hara lebih cepat diabsorpsi oleh akar. Pupuk Gandasil D juga lebih efektif untuk menanggulangi kekurangan unsur mikro. Menurut Rinsema (1983) peningkatan tinggi tanaman merupakan suatu pencerminan dari pertumbuhan tanaman yang menyebabkan perpanjangan ruas - ruas tanaman akibat memanjang dan membesarnya sel - sel. Seiring dengan bertambahnya umur tanaman, untuk pertumbuhan suatu tanaman ditentukan oleh tersedianya unsur hara dalam tanah.

Haryadi (1986) menambahkan bahwa pemberian air dalam kondisi optimal memungkinkan hormon tertentu bekerja secara aktif dalam dinding sel untuk merentang. Kondisi ini pula memacu pembentukan gula yang dapat memperbesar sel - sel sehingga vakuola yang besar terbentuk dan secara relatif mengisap air dalam jumlah besar akibat absorbsi. Keberadaan hormon perentang sel memacu untuk memanjang dan dinding sel bertambah tebal sebagai akibat menumpuknya selulosa tambahan yang terbentuk dari gula. Jadi apabila suatu tanaman membuat 
sel baru, pemanjangan dan pembelahan sel akan mempercepat pertumbuhan batang daun dan sistem perakaran.

\section{Jumlah Daun (helai)}

Hasil analisis statistik menunjukan tidak terjadi interaksi antara berbagai komposisi media tanam (M) dengan berbagai dosis pupuk daun $(\mathrm{G})$ terhadap jumlah daun tanaman pucuk merah. Secara mandiri memberikan pengaruh yang nyata (Tabel 2).

Tabel 2. Respon Tanaman Pucuk Merah Terhadap Berbagai Komposisi Media Tanam dan Dosis Pupuk Gandasil D Terhadap Jumlah Daun 90 HST.

\begin{tabular}{l|c}
\hline \multicolumn{1}{c|}{ Perlakuan } & Rata - rata \\
\hline Komposisi Media Tanam $(\mathrm{M})$ & \\
$\mathrm{m}_{1}=$ Tanah : Bokashi : Sekam $(50: 25: 25)$ & $120,56 \mathrm{~b}$ \\
$\mathrm{~m}_{2}=$ Tanah : Bokashi : Arang sekam $(25: 50: 25)$ & $120,76 \mathrm{~b}$ \\
$\mathrm{~m}_{3}=$ Tanah : Bokashi : Serbuk gergaji $(25: 25:$ & $119,39 \mathrm{a}$ \\
$50)$ & $122,07 \mathrm{c}$ \\
$\mathrm{m}_{4}=$ Tanah : Bokashi : Cocopeat $(50: 25: 25)$ & \\
\hline Dosis Pupuk Gandasil D $(\mathrm{G})$ & \\
$\mathrm{g}_{1}=0$ gram/polybag & $118,94 \mathrm{a}$ \\
$\mathrm{g}_{2}=1$ gram/polybag & $121,13 \mathrm{~b}$ \\
$\mathrm{~g}_{3}=2$ gram/polybag & $122,91 \mathrm{c}$ \\
$\mathrm{g}_{4}=3$ gram/polybag & $119,80 \mathrm{a}$ \\
\hline
\end{tabular}

Keterangan: Angka rata-rata yang diikuti huruf yang sama pada setiap kolom berbeda tidak nyata menurut Uji Jarak Berganda Duncan taraf 5\%.

Taraf faktor $\mathrm{m}_{3}$, yaitu campuran media tanah, bokashi dan serbuk gergaji komposisi ( $25: 25: 50)$, menunjukan rata - rata jumlah daun yang lebih sedikit dari faktor lainnya. Hal ini diduga karena serbuk gergaji merupakan media yang apabila digunakan terlalu lama akan menimbulkan pertumbuhan bakteri dan jamur. Bakteri dan jamur ini mengkontaminasi media tanam yang digunakan. Media yang mengandung bakteri dan jamur akan mengganggu proses penyerapan air dan hara dari akar sehingga proses pengangkutan zat hara tidak maksimal, akhirnya berakibat pada lambatnya pertumbuhan tanaman. Terganggunya penyerapan hara akan menghambat proses fisiologis tanaman salahsatunya menghambat pertumbuhan daun (Junita, dkk., 2002).

Faktor perlakuan $\mathrm{g}_{4}$ yaitu dosis tertinggi pupuk Gandasil 3 gram/polybag menunjukan rata - rata jumlah daun yang lebih sedikit dibandingkan dengan dosis dibawahnya yaitu 2 gram/polybag taraf faktor $\mathrm{g}_{3}$. Hal ini diduga tanaman tidak mampu tumbuh dan berkembang secara optimum pada dosis ini, karena unsur makro dan mikro yang terdapat dalam pupuk Gandasil D sudah cukup tinggi. 
Pemberian perlakuan dengan konsentrasi tinggi akan berperan antagonis terhadap tanaman sehingga dapat menghambat pertumbuhan.

Menurut Hochmuth et al. (2009) bahwa kelebihan unsur hara seperti N, P dan $\mathrm{K}$ pada daerah perakaran dapat mengurangi pertumbuhan tanaman karena kelebihan hara tersebut akan mengurangi penyerapan hara lainnya seperti Zn, Fe, dan $\mathrm{Cu}$, sehingga terjadi defisiensi ketiga unsur tersebut.

\section{Luas Daun $\left(\mathrm{cm}^{2}\right)$}

Hasil analisis statistik menunjukan tidak terjadi interaksi antara berbagai komposisi media tanam (M) dengan berbagai dosis pupuk daun $(\mathrm{G})$ terhadap luas daun tanaman pucuk merah. Secara mandiri memberikan pengaruh nyata (Tabel 3).

Tabel 3. Respon Tanaman Pucuk Merah Terhadap Berbagai Komposisi Media Tanam dan Dosis Pupuk Gandasil D Terhadap Luas Daun 90 HST.

\begin{tabular}{l|l}
\hline \multicolumn{1}{c|}{ Perlakuan } & Rata - rata \\
\hline Komposisi Media Tanam $(\mathrm{M})$ & \\
$\mathrm{m}_{1}=$ Tanah : Bokashi : Sekam $(50: 25: 25)$ & $241,96 \mathrm{a}$ \\
$\mathrm{m}_{2}=$ Tanah : Bokashi : Arang sekam $(25: 50: 25)$ & $242,14 \mathrm{a}$ \\
$\mathrm{m}_{3}=$ Tanah : Bokashi : Serbuk gergaji $(25: 25:$ & $241,10 \mathrm{a}$ \\
$50)$ & $242,24 \mathrm{a}$ \\
$\mathrm{m}_{4}=$ Tanah : Bokashi : Cocopeat $(50: 25: 25)$ & \\
\hline Dosis Pupuk Daun $(\mathrm{G})$ & \\
$\mathrm{g}_{1}=0$ gram/polybag & $240,08 \mathrm{a}$ \\
$\mathrm{g}_{2}=1$ gram/polybag & $242,80 \mathrm{~b}$ \\
$\mathrm{~g}_{3}=2$ gram/polybag & $243,26 \mathrm{~b}$ \\
$\mathrm{~g}_{4}=3$ gram/polybag & $241,30 \mathrm{a}$ \\
\hline
\end{tabular}

Keterangan: Angka rata-rata yang diikuti huruf yang sama pada setiap kolom berbeda tidak nyata menurut Uji Jarak Berganda Duncan taraf 5\%.

Taraf faktor $\mathrm{m}_{4}$, yaitu campuran media tanah, bokashi dan cocopeat komposisi ( $25: 25: 50)$, menunjukan rata - rata luas daun yang lebih tinggi dari faktor lainnya. Hal ini karena penambahan bokashi dan cocopeat dengan dosis yang tepat pada media tanam dapat memperbaiki sifat tanah diantaranya adalah mengefektifkan pemupukan, selain dari memperbaiki sifat tanah (porositas, aerasi). Bokashi dan cocopeat juga berfungsi sebagai pengikat hara (ketika kelebihan hara) yang dapat digunakan tanaman ketika kekurangan hara. Hara dilepas secara perlahan sesuai kebutuhan tanaman/slow release, dengan demikian tanaman dapat tumbuh dan berkembang secara maksimal salah satunya menghasilkan luas daun (Komarayati $d k k, 2003$ ).

Faktor perlakuan $\mathrm{g}_{3}$ yaitu dosis pupuk Gandasil 2 gram/polybag menunjukan rata - rata luas daun yang lebih tinggi dari faktor lainnya. Dosis pupuk 
daun yang tepat dapat meningkatkan luas daun. Pemberian unsur hara makro dan mikro yang tepat sangat dibutuhkan untuk setiap tahap pertumbuhan, khususnya pada pembentukan daun. Pada tanaman jika terjadi kekurangan (defisiensi) unsur terutama N, P dan K maka tumbuh lambat dan kerdil, sementara itu daun yang lebih tua menguning dan akhirnya kering. Kelebihan nitrogen pula akan menyebabkan tanaman menjadi tumbuh lambat salahsatunya mengurangi jumlah dan luas daun serta menunda pembentukan bunga (Novizan, 2002).

\section{Bobot Kering Per Tanaman (g)}

Hasil analisis statistik menunjukan tidak terjadi interaksi antara berbagai komposisi media tanam (M) dengan berbagai dosis pupuk daun $(\mathrm{G})$ terhadap bobot kering tanaman pucuk merah. Secara mandiri memberikan pengaruh yang nyata (Tabel 4).

\section{Tabel 4. Respon Tanaman Pucuk Merah Terhadap Berbagai Komposisi Media Tanam dan Dosis Pupuk Gandasil D Terhadap Bobot Kering 90 HST.}

\begin{tabular}{l|c}
\hline \multicolumn{1}{c|}{ Perlakuan } & Rata - rata \\
\hline Komposisi Media Tanam $(\mathrm{M})$ & \\
$\mathrm{m}_{1}=$ Tanah : Bokashi : Sekam $(50: 25: 25)$ & $8,33 \mathrm{a}$ \\
$\mathrm{m}_{2}=$ Tanah : Bokashi : Arang sekam $(25: 50: 25)$ & $8,67 \mathrm{~b}$ \\
$\mathrm{~m}_{3}=$ Tanah : Bokashi : Serbuk gergaji $(25: 25: 50)$ & $7,58 \mathrm{a}$ \\
$\mathrm{m}_{4}=$ Tanah : Bokashi : Cocopeat $(50: 25: 25)$ & $9,65 \mathrm{c}$ \\
\hline Dosis Pupuk Daun $(\mathrm{G})$ & \\
$\mathrm{g}_{1}=0$ gram/polybag & $8,05 \mathrm{a}$ \\
$\mathrm{g}_{2}=1$ gram/polybag & $7,40 \mathrm{a}$ \\
$\mathrm{g}_{3}=2$ gram/polybag & $9,92 \mathrm{c}$ \\
$\mathrm{g}_{4}=3$ gram/polybag & $8,86 \mathrm{~b}$ \\
\hline
\end{tabular}

Keterangan: Angka rata-rata yang diikuti huruf yang sama pada setiap kolom berbeda tidak nyata menurut Uji Jarak Berganda Duncan taraf 5\%.

Taraf faktor $\mathrm{m}_{4}$, yaitu campuran media tanah, bokashi dan cocopeat komposisi ( $50: 25: 25)$, menunjukan rata - rata bobot kering yang lebih tinggi dari faktor lainnya. Hal ini karena cocopeat merupakan media yang dapat meningkatkan sifat fisik tanah dan dapat menahan air serta unsur hara sehingga dapat di absorpsi oleh akar untuk kebutuhan fotosintesis (Komarayati $d k k, 2003$ ).

Faktor perlakuan $\mathrm{g}_{3}$ yaitu dosis pupuk Gandasil 2 gram/polybag menunjukan rata - rata bobot kering yang lebih tinggi dari faktor lainnya. Hal ini diduga pemberian dosis tersebut optimal untuk proses fotosintesis. Besarnya nilai bobot kering tanaman sangat tergantung dari proses fotosintesis yang dilakukan. Proses fotosintesis merupakan proses memasak makanan dalam daun yang memerlukan bahan dasar yang berupa bahan organik, air dan matahari. 
Ketersediaan bahan organik dan air tersebut sangat tergantung pada kemampuan media dalam menyediakan kedua bahan tersebut. Tiap komposisi media tanam memiliki kemampuan yang berbeda dalam menyediakan bahan organik dan air bagi pertumbuhan tanaman. Kemampuan tersebut sangat dipengaruhi oleh sifat biologi (tekstur dan struktur), sifat kimia (KTK, pH dan suhu) dan biologi (kandungan mikrobiologi tanah).

Menurut (Dwijiseputro, 1990) bahwa pertumbuhan tinggi tanaman, batang dan jumlah daun yang baik akan menghasilkan berat kering total tanaman yang lebih baik. Berat kering total tanaman merupakan hasil keseimbangan antara pengambilan karbondioksida dan pengeluaran oksigen secara nyata ditunjukan pada berat segar tanaman. Begitu pula dengan laju fotosintesis yang berpengaruh terhadap berat kering tanaman dimana semakin tinggi laju fotosintesis semakin meningkat pula berat kering tanaman.

Menurut Anas (1979), berat kering yang dihasilkan oleh suatu tanaman sangat bergantung pada perkembangan daun. Proses fotosintesis adalah suatu faktor yang penting dalam pertumbuhan tanaman dimana banyaknya daun yang tinggi dapat menerima sinar matahari yang tinggi pula. Hasil fotosintesis kemudian diedarkan keseluruh organ tanaman yang membutuhkan dan menyebabkan bahan kering tanaman menjadi tinggi.

\section{Diameter Batang $\left(\mathbf{m m}^{2}\right)$}

Hasil analisis statistik menunjukan tidak terjadi interaksi antara berbagai komposisi media tanam (M) dengan berbagai dosis pupuk daun (G) terhadap diameter batang pucuk merah. Secara mandiri memberikan pengaruh yang nyata (Tabel 5).

\section{Tabel 5. Respon Tanaman Pucuk Merah Terhadap Berbagai Komposisi Media Tanam dan Dosis Gandasil D Terhadap Diameter Batang 90 HST.}

\begin{tabular}{l|c}
\hline \multicolumn{1}{c|}{ Perlakuan } & Rata - rata \\
\hline Komposisi Media Tanam $(\mathrm{M})$ & \\
$\mathrm{m}_{1}=$ Tanah : Bokashi : Sekam $(50: 25: 25)$ & $22,64 \mathrm{a}$ \\
$\mathrm{m}_{2}=$ Tanah : Bokashi : Arang sekam $(25: 50: 25)$ & $23,16 \mathrm{a}$ \\
$\mathrm{m}_{3}=$ Tanah : Bokashi : Serbuk gergaji $(25: 25: 50)$ & $22,11 \mathrm{a}$ \\
$\mathrm{m}_{4}=$ Tanah : Bokashi : Cocopeat $(50: 25: 25)$ & $24,15 \mathrm{~b}$ \\
\hline Dosis Pupuk Gandasil D $(\mathrm{G})$ & \\
$\mathrm{g}_{1}=0$ gram/polybag & $21,08 \mathrm{a}$ \\
$\mathrm{g}_{2}=1$ gram/polybag & $23,73 \mathrm{c}$ \\
$\mathrm{g}_{3}=2$ gram/polybag & $24,94 \mathrm{~d}$ \\
$\mathrm{~g}_{4}=3$ gram/polybag & $22,30 \mathrm{~b}$ \\
\hline
\end{tabular}

Keterangan: Angka rata-rata yang diikuti huruf yang sama pada setiap kolom berbeda tidak nyata menurut Uji Jarak Berganda Duncan taraf 5\%. 
Taraf faktor $\mathrm{m}_{4}$, yaitu campuran media tanah, bokashi dan cocopeat komposisi $(50: 25: 25)$, menunjukan rata - rata diameter batang yang lebih tinggi dari faktor lainnya. Hal ini karena media tanam tanah, bokashi dan cocopeat merupakan komposisi media tanam yang seimbang yang dapat meningkatkan sifat fisik tanah, menahan air dan unsur hara untuk memenuhi kebutuhan tanaman. Media campuran tanah, bokashi dan cocopeat mengandung berbagai unsur hara yang bersifat organik. Pengaplikasian beserta pupuk daun yang bersifat hormon atau zat pengatur tumbuh menjadikan proses dekomposisi hara menjadi optimum. Akhirnya akan menambah pertumbuhan serta perkembangan pada tanaman salah satunya pada ukuran batang atau diameter batang (Hanafiah, 2007).

Pertumbuhan batang berlangsung pada fase pertumbuhan vegetatif. Fasenya berhubungan dengan tiga proses penting yaitu pembelahan sel, pemanjangan sel dan tahap pertama dari diferensiasi sel. Ketiga proses tersebut membutuhkan zat hara salahsatunya karbohidrat. Karbohidrat yang terbentuk akan bersenyawa dengan nitrogen untuk membentuk protoplasma pada titik tumbuh yang akan mempengaruhi pertambahan cabang dan lebar batang. Ketersediaan karbohidrat yang dibentuk dalam tanaman dipengaruhi oleh ketersediaan hara bagi tanaman tersebut salahsatunya faktor media tanam. (Harlina, 2003).

Faktor perlakuan $\mathrm{g}_{3}$ yaitu dosis pupuk Gandasil 2 gram/polybag menunjukan rata - rata diameter batang yang lebih tinggi dari faktor lainnya. Hal ini diduga pemberian unsur hara makro maupun mikro melalui pupuk Gandasil sangat berpengaruh dalam pertumbuhan batang dibandingkan dengan yang tidak memakai perlakuan $\left(g_{1}\right)$. Unsur hara berperan sangat penting, apabila tanaman kekurangan hara maka akan mempengaruhi proses fotosintesis yang mengakibatkan terganggunya proses pertumbuhan serta perkembangan tanaman salahsatunya diameter batang. Unsur hara yang cukup sangat penting bagi pembentukan bagian tanaman karena sepanjang pertumbuhan tanaman memerlukan pertukaran zat secara intensifnya. Pertumbuhan berlangsung baik dengan sendirinya apabila unsur hara terpenuhi (Harlina, 2003).

\section{Panjang Akar (cm)}

Hasil analisis statistik menunjukan tidak terjadi interaksi antara berbagai komposisi media tanam (M) dengan berbagai dosis pupuk daun (G) terhadap panjang akar pucuk merah. Secara mandiri memberikan pengaruh yang nyata (Tabel 6). 
Tabel 6. Respon Tanaman Pucuk Merah Terhadap Berbagai Komposisi Media Tanam dan Dosis Pupuk Gandasil D Terhadap Panjang Akar 90 HST.

\begin{tabular}{l|c}
\hline \multicolumn{1}{c|}{ Perlakuan } & Rata - rata \\
\hline Komposisi Media Tanam $(\mathrm{M})$ & \\
$\mathrm{m}_{1}=$ Tanah : Bokashi : Sekam $(50: 25: 25)$ & $25,63 \mathrm{a}$ \\
$\mathrm{m}_{2}=$ Tanah : Bokashi : Arang sekam $(25: 50: 25)$ & $26,14 \mathrm{a}$ \\
$\mathrm{m}_{3}=$ Tanah : Bokashi : Serbuk gergaji $(25: 25: 50)$ & $25,11 \mathrm{a}$ \\
$\mathrm{m}_{4}=$ Tanah : Bokashi : Cocopeat $(50: 25: 25)$ & $27,14 \mathrm{~b}$ \\
\hline Dosis Pupuk Gandasil D $(\mathrm{G})$ & \\
$\mathrm{g}_{1}=0$ gram/polybag & $24,08 \mathrm{a}$ \\
$\mathrm{g}_{2}=1$ gram/polybag & $26,71 \mathrm{c}$ \\
$\mathrm{g}_{3}=2$ gram/polybag & $27,94 \mathrm{~d}$ \\
$\mathrm{~g}_{4}=3$ gram/polybag & $25,29 \mathrm{~b}$ \\
\hline $\mathrm{K}$
\end{tabular}

Keterangan: Angka rata-rata yang diikuti huruf yang sama pada setiap kolom berbeda tidak nyata menurut Uji Jarak Berganda Duncan taraf 5\%.

Taraf faktor $\mathrm{m}_{4}$, yaitu campuran media tanah, bokashi dan cocopeat komposisi $(50: 25: 25)$, menunjukan rata - rata panjang akar yang lebih tinggi dari faktor lainnya. Hal ini karena penambahan cocopeat mampu mengikat serta menjaga kapasitas air cukup tinggi yaitu mencapai 14,71 kali bobot keringnya. Media tanam kemudian dapat menyimpan kadar air lebih lama untuk penyerapan hara oleh akar tanaman (Sutater et al, 1998). Penambahan cocopeat beserta unsur hara menjadikan optimumnya aktivitas akar sehingga memacu pada panjang akar serta bagian tanaman lainnya seperti diameter dan tinggi tanaman (Arif Irawan, 2014).

Faktor perlakuan $\mathrm{g}_{3}$ yaitu dosis pupuk Gandasil 2 gram/polybag menunjukan rata - rata panjang akar yang lebih tinggi dari faktor lainnya. Hal ini diduga senyawa dalam pupuk Gandasil yang diberikan lewat tanah dapat meningkatkan aktivitas akar, sehingga menimbulkan perkembangan akar dalam tanah, baik panjang maupun banyaknya akar. Leiwakabessy dan Sutandi (1998) menyatakan bahwa kemampuan tanaman untuk menyerap hara dan air selain tergantung pada sifat morfologi dan fisiologi akar, selain itu kandungan hara dalam tanah juga berpengaruh.

\section{KESIMPULAN}

Berdasarkan penelitian respon tanaman pucuk merah (Syzygium campanulatum $K$ ) terhadap berbagai komposisi media tanam dan dosis pupuk Gandasil D dapat disimpulkan: 
1. Tidak terjadi interaksi antara berbagai komposisi media tanam dan dosis pupuk Gandasil D terhadap pertumbuhan tanaman pucuk merah.

2. Komposisi antara media tanah, bokashi dan cocopeat $(50: 25: 25)$ berpengaruh nyata terhadap tinggi tanaman, jumlah daun, luas daun, bobot kering, diameter batang dan panjang akar. Pupuk Gandasil D dengan dosis 2 gram/polybag, berpengaruh nyata terhadap tinggi tanaman, jumlah daun, luas daun, bobot kering, diameter batang dan panjang akar.

\section{DAFTAR PUSTAKA}

Aisha, dkk. 2013. Syzygium Campanulatum Korth Methanolic Extract Inhibits Angiogenesis and Tumor Growth In Nude Mice BMC Complementary and alternative medicine. Vol. 13. Article 168.

Anas I. 1989. Biologi Tanah Dalam Praktek. Direktorat Pendidikan Tinggi Pusat Antar Universitas Bioteknologi, IPB. Bogor.

Arif Irawan. 2014. Pemanfaatan Cocopeat dan Arang Sekam Padi Sebagai Media Tanam Bibit Cempaka (Elmerrilia ovalis). Jurnal Kehutanan.

Direktorat Jendral Hortikultura. 2012. Perkembangan Volume Ekspor Hortikultura. Publikasi tanggal 22 Juni 2012. Diakses tanggal 17 Januari 2017. http://hortikultura.deptan.go.id.

Dwidjoseputro. 1994. Pengantar Fisiologi Tumbuhan. Jakarta. PT Gramedia Pustaka Utama.

Hanafiah, 2007. Dasar - Dasar Ilmu Tanah. PT. Raja Grafindo Persada. Jakarta.

Harjadi, S. 1989. Dasar-Dasar Hortikultura. Jurusan Budidaya Pertanian. Fakultas Pertanian-IPB. Bogor.

Harlina, N. 2003. Pemanfaatan Pupuk Majemuk Sebagai Sumber Hara Budidaya Terong Secara Hidroponik. Skripsi. Fakultas Pertanian IPB Bogor.

Hochmuth, et al. 2009. Plant Analysis and Interpretation for Vegetable Crops in Florida. Florida Cooperative Extension Service. Institute of Food and Agricultural Sciences. University of Florida.

Junita, dkk. 2002. Pengaruh Frekuensi Penyiraman dan Takaran Pupuk Kandang Terhadap Pertumbuhan dan Hasil Patchauli. Jurnal Ilmu Pertanian UGM.

Komarayati S, Pari G dan Gusmailina. 2003. Pengembangan Penggunaan Arang untuk Rehabilitasi Lahan dalam Buletin Penelitian dan Pengembangan Kehutanan. Jakarta: Badan Penelitian dan Pengembangan Kehutanan.

Leiwakabessy dan Sutandi. 1998. Pupuk dan Pemupukan. Jurusan Tanah. Fakultas Pertanian IPB. Bogor. Hal 183.

Novizan. 2007. Petunjuk Pemupukan yang Efektif. Agro Media Pustaka. Jakarta.

Pinus Lingga dan Marsono. 2001. Petunjuk Penggunaan Pupuk. Cet. Ke- 12. Penebar Swadaya. Jakarta.

Rinsema, M.T., 1986. Pupuk dan Cara pemupukan. Bratara Karya Aksara, Jakarta. Setyamidjaja. 1986. Pupuk dan Pemupukan. Simplex, Jakarta. 